TITLE:

\title{
First-principles study of substitutional magnesium and zinc in hydroxyapatite and octacalcium phosphate
}

\author{
$\operatorname{AUTHOR}(\mathrm{S})$ :
}

Matsunaga, Katsuyuki

\section{CITATION:}

Matsunaga, Katsuyuki. First-principles study of substitutional magnesium and zinc in hydroxyapatite and octacalcium phosphate. JOURNAL OF CHEMICAL PHYSICS 2008, 128(24): 245101.

ISSUE DATE:

2008-06-28

URL:

http://hdl.handle.net/2433/84601

\section{RIGHT:}

Copyright 2008 American Institute of Physics. This article may be downloaded for personal use only. Any other use requires prior permission of the author and the American Institute of Physics. 


\title{
First-principles study of substitutional magnesium and zinc in hydroxyapatite and octacalcium phosphate
}

\author{
Katsuyuki Matsunaga ${ }^{\text {a) }}$ \\ Department of Materials Science and Engineering, Kyoto University, Yoshida-Honmachi, Sakyo, \\ Kyoto 606-8501, Japan and Nanostructure Research Laboratory, Japan Fine Ceramics Center, 2-4-1, \\ Mutsuno, Atsuta, Nagoya, 456-8587 Japan
}

(Received 17 March 2008; accepted 14 May 2008; published online 24 June 2008)

\begin{abstract}
First-principles calculations are performed for $\mathrm{Mg}^{2+}$ and $\mathrm{Zn}^{2+}$ substitution in hydroxyapatite (HAp) and octacalcium phosphate (OCP), because the foreign ions are known to play an important role for bone formation. In order to study their possible location in the system of HAp in contact with the aqueous solution, OCP is considered as a structural model of the transition region between HAp and the solution. It is found that, when the foreign ions substitute for Ca sites, the surrounding oxygen ions undergo considerable inward relaxation, due to their smaller ionic sizes than $\mathrm{Ca}^{2+}$, which results in the smaller coordination numbers with oxygen as compared with those of $\mathrm{Ca}$ in bulk HAp and OCP. From the calculated defect formation energies, it is likely that the substitutional foreign ions are quite difficult to dissolve into HAp whereas can be more easily incorporated in OCP. In particular, $\mathrm{Zn}^{2+}$ can more favorably substitute for the specific Ca site of OCP, as compared to $\mathrm{Mg}^{2+}$, which is attributed with covalent bond formation between $\mathrm{Zn}$ and the surrounding oxygen ions. It is thus considered that zinc may play its role to promote bone formation by being incorporated into the transition region between HAp and the surrounding solution. (c) 2008 American Institute of Physics. [DOI: 10.1063/1.2940337]
\end{abstract}

\section{INTRODUCTION}

In normal bone remodeling processes, successive bone resorption and formation take place with the aid of osteoclast and osteoblast activity. Imbalance between bone resorption and formation results in osteoporosis, which is a bone disease characterized by decreased bone mass and density. Since hard tissues such as bone and tooth enamel contain hydroxyapatite $\left[\mathrm{Ca}_{10}\left(\mathrm{PO}_{4}\right)_{6}(\mathrm{OH})_{2}(\mathrm{HAp})\right]$ as inorganic components, it is essential to clarify physical and chemical properties of biological HAp and to obtain a fundamental understanding of the bone mineralization processes.

It is known that hard tissues in human bodies contain a variety of trace elements, which likely play important biological roles. Typical trace elements in bones and tooth enamels are $\sim 4-8 \mathrm{wt} \%$ of carbonate $\left(\mathrm{CO}_{3}{ }^{2-}\right)$, $\sim 0.4-0.9$ wt $\%$ of sodium and magnesium, and approximately less than $0.1 \mathrm{wt} \%$ of potassium, fluoride, and chloride. ${ }^{1}$ Among trace elements involved in bones and the surrounding aqueous solutions (body fluids), magnesium and zinc ions are expected to have a significant effect on bone mineralization. The content of $\mathrm{Mg}^{2+}$ in biological apatites is basically larger than that of $\mathrm{Zn}^{2+}$, and the trace elements are considered to be uptaken and/or released by bone-mineral components during the bone remodeling process. Regarding the trace-element effects on bone formation, it was reported that the $\mathrm{Mg}^{2+}$ deficiency gives rise to decreased bone mass, due to decreased osteoblasts and increased osteoclasts. ${ }^{2}$ While it is known that $\mathrm{Zn}^{2+}$ addition can stimulate osteoblast

\footnotetext{
${ }^{a)}$ Author to whom correspondence should be addressed. Electronic mail: k.matsunaga@materials.mbox.media.kyoto-u.ac.jp.
}

activity and thus promote bone formation. ${ }^{3}$ Hayakawa et al. also reported that Zn-doped HAp particles exhibit selective protein adsorption. ${ }^{4}$ It is expected, therefore, that $\mathrm{Mg}$ and $\mathrm{Zn}$ dopants may play a potential role for adsorption of proteins and cells on biological apatites. In addition to their biological effect, these ions are known to inhibit crystallization and growth of HAp, which indicates that they also affect formation, crystal sizes, and morphology of the HAp minerals in bone and tooth. ${ }^{5-8}$

In order to clarify the effects of $\mathrm{Mg}^{2+}$ and $\mathrm{Zn}^{2+}$ on bone formation in more detail, it is necessary to investigate their location and chemical environments in the system of HAp and its surrounding solution at the atomic and electronic levels. In particular, the role of the trace elements for bone formation may be different depending on their location. When the situation that HAp is in contact with an aqueous solution is considered, ${ }^{9,10}$ it can be simply imagined that there are three main possibilities of the locations of the trace elements; (1) substitution for $\mathrm{Ca}^{2+}$ in the HAp lattice, (2) the incorporation in a transition region between HAp and the solution, and (3) being loosely bound at HAp surfaces or in the solution. In the first case, it is considered that the trace elements cannot directly affect the bone formation but could play its role only when the ions are released by dissolution of HAp crystals. The second case could promote adsorption of osteoblast cells on the transition region and could directly stimulate the activity of the adsorbed cells. Since apatite crystals in mineralized bones are always thin and platelet with a thickness of about $4 \mathrm{~nm},{ }^{1}$ many atoms in the crystals may be considered to be located in the transition region. Therefore, it is inevitably important to investigate impurity 
location in the transition region as well as in HAp. However, the transition region may have a low-crystalline state or a hydrated state of calcium phosphate, and its detailed structure has not been characterized because that phase may be metastable. ${ }^{11-13}$ In this regard, Brown et al. proposed that the structure of the transition region is similar to the structure of octacalcium phosphate $\left[\mathrm{Ca}_{8} \mathrm{H}_{2}\left(\mathrm{PO}_{4}\right)_{6} \cdot 5 \mathrm{H}_{2} \mathrm{O}(\mathrm{OCP})\right]$, which has ionic arrangements of $\mathrm{Ca}^{2+}$ and $\mathrm{PO}_{4}{ }^{3-}$ similar to HAp and also contains $\mathrm{H}_{2} \mathrm{O}$ molecules (details will be shown later). ${ }^{14}$ Santos et al. and Cazalbou et al. also suggested the presence of the metastable hydrated layer containing $\mathrm{HPO}_{4}{ }^{2-}$ and structural water molecules on the HAp surface, which resembles the OCP structure. ${ }^{12,13}$ In the third case, the ions may directly act on osteoblast cells to promote protein synthesis and enzyme activity. In order to understand the bone formation mechanism by the trace elements, therefore, it is essential to reveal the possible locations in the system containing HAp and its surrounding solution.

Recently, first-principles calculations have proved to be effective to investigate atomic and electronic structures of point defects even in complicated metal oxides such as apatite-based materials. By analyzing total energies of computational models, it is also feasible not only to reveal characteristic atomic coordinates but also to evaluate defect energetics quantitatively. ${ }^{15,16}$ Regarding $\mathrm{Mg}^{2+}$ and $\mathrm{Zn}^{2+}$ ions in calcium phosphates, Terra et al. employed the embedded cluster model method to study electronic structures of $\mathrm{Zn}^{2+}$ in HAp. ${ }^{17}$ Yin et al. carried out first-principles calculations of $\mathrm{Mg}^{2+}$ and $\mathrm{Zn}^{2+}$ dopants in tricalcium phosphate (TCP) using cluster models, and discussed the bioactivity of the TCP materials from the structural characteristics around the dopants. ${ }^{18}$ More recently, Ma and Ellis calculated Zn substitution on the HAp (0001) surface, using the surface slab models, and evaluated adsorption energies at $\mathrm{Ca}$ sites around the surface. ${ }^{19}$ Although these studies provided detailed atomic structures around the dopants, they did not evaluate thermodynamic stability of $\mathrm{Mg}^{2+}$ and $\mathrm{Zn}^{2+}$ in the apatiterelated materials.

In this study, first-principles band-structure calculations are performed for $\mathrm{Mg}^{2+}$ and $\mathrm{Zn}^{2+}$ in HAp. In order to investigate a possibility of their incorporation into the HApsolution transition region, OCP is used as a structural model, and substitution of $\mathrm{Mg}^{2+}$ and $\mathrm{Zn}^{2+}$ for $\mathrm{Ca}$ in OCP is also calculated. Theoretical formation energies of the substitutional defects are evaluated from total energies of supercells, together with chemical potentials determined under chemical equilibrium between HAp and its saturated aqueous solution. The predicted locations of the trace elements are discussed in connection with their role in the bone formation process.

\section{COMPUTATIONAL METHOD}

\section{A. Electronic structure calculation}

First-principles electronic structure calculations are performed based on the projector augmented wave method, implemented in VASP. ${ }^{20-22}$ The generalized gradient approximation (GGA) is used for the exchange-correlation potential, and the GGA functional proposed by Perdew et al. is employed. ${ }^{23}$ A plane-wave cutoff energy $\left(E_{\text {cut }}\right)$ of $500 \mathrm{eV}$ is
TABLE I. The calculated interatomic distances and coordination numbers from $\mathrm{Ca}$ and $\mathrm{P}$ to their neighboring atoms in bulk HAp and OCP.

\begin{tabular}{|c|c|c|}
\hline \multirow[b]{2}{*}{ Atomic site } & \multicolumn{2}{|c|}{ Distances (nm) (atomic species; coordination number) } \\
\hline & First NN & Second NN \\
\hline \multicolumn{3}{|c|}{ HAp } \\
\hline $\mathrm{Ca}-1$ & $0.244(\mathrm{O} ; 3), 0.248(\mathrm{O} ; 3)$ & $0.280(\mathrm{O} ; 3)$ \\
\hline $\mathrm{Ca}-2$ & $\begin{array}{l}0.236(\mathrm{O} ; 3), 0.240(\mathrm{O} ; 1) \\
0.248(\mathrm{O} ; 1), 0.252(\mathrm{O} ; 1)\end{array}$ & $0.269(\mathrm{H} ; 1), 0.281(\mathrm{O} ; 1)$ \\
\hline $\mathrm{P}$ & $0.156(O ; 4)$ & \\
\hline \multicolumn{3}{|c|}{ OCP } \\
\hline $\mathrm{Ca}-1$ & $\begin{array}{l}0.241(\mathrm{O} ; 1), 0.246(\mathrm{O} ; 4) \\
0.251(\mathrm{O} ; 1), 0.267(\mathrm{O} ; 1)\end{array}$ & $0.279(\mathrm{O} ; 1)$ \\
\hline $\mathrm{Ca}-2$ & $\begin{array}{l}0.238(\mathrm{O} ; 3), 0.241(\mathrm{O} ; 1) \\
0.250(\mathrm{O} ; 2), 0.263(\mathrm{O} ; 1)\end{array}$ & $0.301(\mathrm{O} ; 1)$ \\
\hline $\mathrm{Ca}-3$ & $\begin{array}{l}0.228(\mathrm{O} ; 1), 0.239(\mathrm{O} ; 1) \\
0.247(\mathrm{O} ; 3), 0.256(\mathrm{O} ; 1)\end{array}$ & $0.287(\mathrm{O} ; 1)$ \\
\hline $\mathrm{Ca}-4$ & $\begin{array}{l}0.234(\mathrm{O} ; 1), 0.238(\mathrm{O} ; 2) \\
0.246(\mathrm{O} ; 1), 0.254(\mathrm{O} ; 2) \\
0.261(\mathrm{O} ; 1)\end{array}$ & $0.295(\mathrm{H} ; 1)$ \\
\hline $\mathrm{Ca}-5$ & $\begin{array}{l}0.234(\mathrm{O} ; 1), 0.237(\mathrm{O} ; 2) \\
0.242(\mathrm{O} ; 1), 0.246(\mathrm{O} ; 1) \\
0.249(\mathrm{O} ; 1)\end{array}$ & $0.275(\mathrm{H} ; 1)$ \\
\hline $\mathrm{Ca}-6$ & $\begin{array}{l}0.227(\mathrm{O} ; 3), 0.237(\mathrm{O} ; 1) \\
0.251(\mathrm{O} ; 1), 0.271(\mathrm{O} ; 1)\end{array}$ & $0.287(\mathrm{O} ; 1)$ \\
\hline $\mathrm{Ca}-7$ & $\begin{array}{l}0.231(\mathrm{O} ; 1), 0.237(\mathrm{O} ; 2) \\
0.246(\mathrm{O} ; 1), 0.250(\mathrm{O} ; 2) \\
0.258(\mathrm{O} ; 1)\end{array}$ & $0.279(\mathrm{H} ; 1)$ \\
\hline $\mathrm{Ca}-8$ & $\begin{array}{l}0.238(\mathrm{O} ; 1), 0.240(\mathrm{O} ; 2) \\
0.242(\mathrm{O} ; 2), 0.267(\mathrm{O} ; 1)\end{array}$ & $0.308(\mathrm{O} ; 1), 0.311(\mathrm{P} ; 1)$ \\
\hline $\mathrm{P}-1$ & $0.156(O ; 4)$ & \\
\hline $\mathrm{P}-2$ & $0.156(O ; 4)$ & \\
\hline $\mathrm{P}-3$ & $0.156(O ; 4)$ & \\
\hline $\mathrm{P}-4$ & $0.156(O ; 4)$ & \\
\hline P-5 & $0.154(\mathrm{O} ; 3), 0.163(\mathrm{O} ; 1)$ & \\
\hline P-6 & $0.155(\mathrm{O} ; 3), 0.160(\mathrm{O} ; 1)$ & \\
\hline
\end{tabular}

used throughout the present study. Based on forces on atoms calculated, all atoms in unit cells and supercells are allowed to relax until their forces converge to less than $0.05 \mathrm{eV} / \AA$.

In this study, substitutional $\mathrm{Mg}^{2+}$ and $\mathrm{Zn}^{2+}$ for $\mathrm{Ca}^{2+}$ in HAp and OCP are calculated. Since these are divalent cations, additional charge compensating defects do not need to be considered for the ion substitutions. For HAp, the hexagonal structure (space group $P 6_{3} / m$ ) having 44 atoms is used. ${ }^{24}$ It is noted that the $\mathrm{P}$ atom is surrounded by four $\mathrm{O}$ atoms with a bond length of $0.156 \mathrm{~nm}$, two kinds of Ca sites, Ca-1 and $\mathrm{Ca}-2$, are present, and the $\mathrm{OH}^{-}$ions are not in the positions related by the mirror planes at $z=1 / 4$ and $3 / 4$. The Ca-1 ions are sixfold coordinated by oxygen ions at the vertices of $\mathrm{PO}_{4}$ tetrahedra, with a $\mathrm{Ca}-\mathrm{O}$ bond length of about $0.24 \mathrm{~nm}$ (see Table I). Since Ca-1 ions form columns along the $c$ axis, therefore, they are sometimes referred to as columnar $\mathrm{Ca}$. The $\mathrm{Ca}-2$ ions are also surrounded by six oxygen ions, and form two Ca triangles rotated by $60^{\circ}$ about the $\mathrm{OH}^{-}$columns parallel to the $c$ axis. Further details of the hexagonal structure were also described in Refs. 24 and 25. The unit-cell structure of the hexagonal phase was already optimized in the same first-principles manner with the present study, ${ }^{15}$ which is used to generate HAp supercells for the defect calculations. 


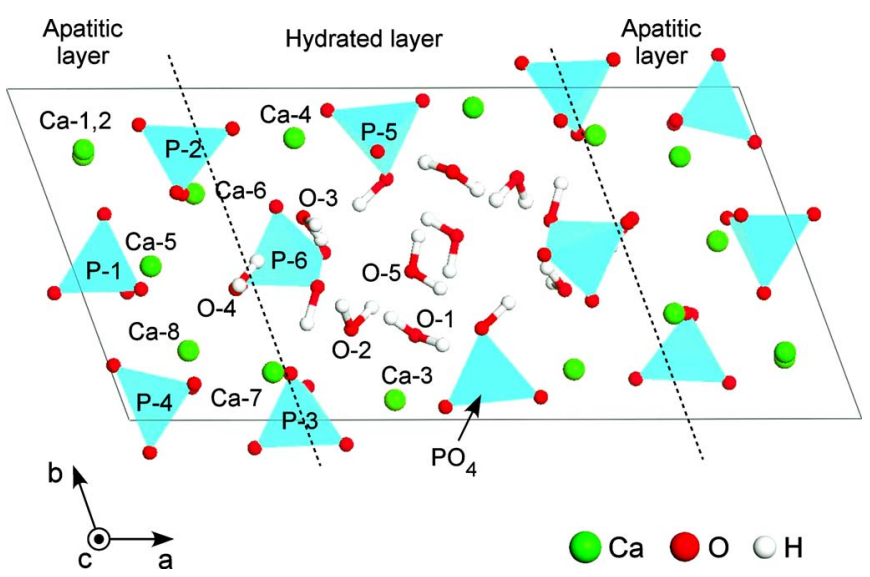

FIG. 1. (Color online) Crystal structure of OCP viewed along the $c$ axis. The $\mathrm{PO}_{4}^{3-}$ groups are represented by the tetrahedra.

Figure 1 displays the unit-cell structure of OCP viewed along the $c$ axis. The crystal structure is triclinic with a space group of $P \overline{1}$ and exhibits the much longer $a$-axis dimension than the $b$ axis. ${ }^{14,26}$ There are eight kinds of $\mathrm{Ca}$ sites and six kinds of $\mathrm{P}$ sites, and the $\mathrm{P}$ atoms are surrounded by four oxygen atoms to form $\mathrm{PO}_{4}$ tetrahedra. According to the notations by Mathew et al., ${ }^{26} \mathrm{PO}_{4}$ tetrahedra centered at P-5 and P-6 are in the form of $\mathrm{HPO}_{4}$ groups by hydrogen attachment. Except for oxygen atoms bonded to the $\mathrm{P}$ atoms, there are five kinds of crystallographically independent $\mathrm{O}$ atoms (O-1 to O-5) forming $\mathrm{H}_{2} \mathrm{O}$ molecules. It is noted that O-3 is statistically disordered and two kinds of O-3 positions, O-3a and $\mathrm{O}-3 \mathrm{~b}$, were designated by Mathew et $a .^{26}$ Many of the $\mathrm{H}_{2} \mathrm{O}$ molecules are coordinated to adjacent $\mathrm{Ca}$ atoms. O- 1 is coordinated to $\mathrm{Ca}-3, \mathrm{O}-2$ to two $\mathrm{Ca}$ atoms of $\mathrm{Ca}-3$ and $\mathrm{Ca}-7$, and $\mathrm{O}-3$ to $\mathrm{Ca}-4$. O-4 is also bonded to $\mathrm{Ca}-5$ and $\mathrm{Ca}-7$, whereas $\mathrm{O}-5$ is not coordinated to $\mathrm{Ca}$ atoms. Due to the center of inversion at $(1 / 2,1 / 2,1 / 2)$, the total number of atoms in the unit cell is 110 .

As shown by Brown et al., ${ }^{14}$ the OCP structure is closely related to HAp. In OCP, the atomic arrangement of $\mathrm{Ca}$ and $\mathrm{PO}_{4}$ in the region of $x=0-1 / 4$ and $x=3 / 4-1$ is similar to that of HAp, and therefore is referred to as the "apatitic layer." Due to the similarity to HAp, OCP is considered as a precursor of HAp in in vitro and in pathological calcification. ${ }^{11}$ It is noted, however, that the local atomic coordinates are more distorted and lower symmetric than those in HAp. In contrast, the remaining region containing the water molecules is called as the hydrated layer, and the composition in this layer $\left(\mathrm{Ca}_{4}\left(\mathrm{HPO}_{4}\right)_{4} \cdot 10 \mathrm{H}_{2} \mathrm{O}\right)$ is close to that of dicalcium phosphate dehydrate $\left[\mathrm{Ca}\left(\mathrm{HPO}_{4}\right) \cdot 2 \mathrm{H}_{2} \mathrm{O}\right]{ }^{27}$ The apatitic and hydrated layers are alternately stacked along the $a$ axis in the OCP structure.

The OCP unit cell is calculated on the Monkhorst-Pack $k$-point mesh of $1 \times 2 \times 3$ (three irreducible $k$ points). ${ }^{28}$ As stated above, since O-3 is disordered, ${ }^{26}$ two kinds of the OCP unit cells comprising $\mathrm{O}-3 \mathrm{a}$ and $\mathrm{O}-3 \mathrm{~b}$ are calculated, so that a total energy of the unit cell containing O-3b is found to be by $0.35 \mathrm{eV}$ smaller than that of the O-3a case. Accordingly, computed results based on the unit cell with $\mathrm{O}-3 \mathrm{~b}$ will be shown hereafter. The optimized unit-cell parameters are $a$
$=2.00 \mathrm{~nm}, b=0.97 \mathrm{~nm}, c=0.69 \mathrm{~nm}, \alpha=90.35^{\circ}, \beta=93.21^{\circ}$, and $\gamma=110.14^{\circ}$, which reproduce experimental data within an accuracy of $1.7 \% .^{26}$

The calculated distances from $\mathrm{Ca}$ and $\mathrm{P}$ to the first and second nearest neighbor (NN) atoms in HAp and OCP are summarized in Table I. In HAp, the Ca-1 and Ca- 2 sites are considered to be sixfold coordinated by oxygen. However, the extended coordination numbers of $\mathrm{Ca}$ within the second NN coordination shell (9 for $\mathrm{Ca}-1$ and 7 for $\mathrm{Ca}-2$ ) are sometimes used to discriminate the difference in atomic coordination of Ca- 1 and $\mathrm{Ca}-2{ }^{25}$ As compared to the HAp case, the $\mathrm{Ca}-\mathrm{O}$ lengths in OCP exhibit a wide range of variation from 0.23 to $0.28 \mathrm{~nm}$, but it can be roughly said from Table I that the coordination numbers of $\mathrm{Ca}$ to $\mathrm{O}$ are 6 or 7 . In contrast, the P-O lengths in OCP are similar to those in HAp (about $0.156 \mathrm{~nm}$ ), and all the $\mathrm{P}$ atoms are fourfold coordinated by oxygen. However, a $\mathrm{H}$ atom attaches to an $\mathrm{O}$ atom of the $\mathrm{PO}_{4}$ tetrahedra centered at $\mathrm{P}-5$ and $\mathrm{P}-6$, and then the $\mathrm{P}-\mathrm{O}$ bond with the hydrogen attachment exhibits a longer bond length (about $0.16 \mathrm{~nm}$ ) than the other three $\mathrm{P}-\mathrm{O}$ bonds.

Based on the optimized unit-cell structures of HAp and OCP, supercells for the defect calculations are generated. In the HAp case, the hexagonal unit cell is doubled in all directions, so that the HAp supercell comprises 352 atoms. While the OCP unit cell is doubled only along the $c$ axis, and the total atomic number of the resultant OCP is 220 atoms. For the supercell calculations, Brillouin zone integrations are performed only at $\Gamma$ point because of the rather large supercells. One of $\mathrm{Ca}$ atoms is replaced by $\mathrm{Mg}$ or $\mathrm{Zn}$, and the substitution at all the inequivalent $\mathrm{Ca}$ sites is individually calculated in both the HAp and OCP cases. All atoms in the defective supercells are allowed to relax in the manner described above, but the cell shape and cell dimensions are kept constant during the structural optimization. This corresponds to the ion substitution in HAp and OCP in the dilute state. If a large amount of the substitutional defects are accommodated in the crystals, defect-defect interactions, statistic defect configurations of defect species, and the associated variations in the lattice parameters of HAp may be taken into account. As a first step, however, it is beneficial to study formation energies of the isolated substitutional defects based on the dilute approximation, in order to reveal fundamental solubility of $\mathrm{Mg}$ and $\mathrm{Zn}$ in HAp and OCP.

In order to check the computational accuracy in the present supercell calculations, test calculations using two irreducible $k$ points are carried out for the OCP supercells with/without $\mathrm{Zn}$ substitution. It is confirmed that the total energy convergence is less than $1.0 \mathrm{meV} /$ atom, which results in a difference in defect formation energy of less than $0.01 \mathrm{eV}$.

\section{B. Defect formation energy}

Defect formation energies $\left(\Delta H_{\mathrm{f}}\right)$ are evaluated from total energies $\left(E_{\mathrm{T}}\right)$ of the perfect and defective supercells. When a divalent foreign ion $\mathrm{M}^{2+}(\mathrm{M}=\mathrm{Mg}$ or $\mathrm{Zn})$ substitutes for $\mathrm{Ca}^{2+}$ in HAp or OCP, $\Delta H_{\mathrm{f}}$ can be written as 


$$
\Delta H_{\mathrm{f}}=E_{\mathrm{T}}(\text { defective })-E_{\mathrm{T}}(\text { perfect })+\bar{\mu}_{\mathrm{Ca}^{2+}}-\bar{\mu}_{\mathrm{M}^{2+}} .
$$

Here $\bar{\mu}_{\mathrm{Ca}^{2+}}$ and $\bar{\mu}_{\mathrm{M}^{2+}}$ indicate electrochemical potentials of $\mathrm{Ca}^{2+}$ and $\mathrm{M}^{2+}$, which are determined from chemical equilibrium of interest. In this study, it is assumed that HAp and OCP crystals equilibrate with an aqueous solution that is saturated with respect to HAp and contains particular amount of $\mathrm{M}^{2+}$ ions. Since the electrochemical potentials of a constituent ionic species in the solid and liquid phases are equal to each other in the chemical equilibrium, $\bar{\mu}_{\mathrm{Ca}^{2+}}$ and $\bar{\mu}_{\mathrm{M}^{2+}}$ can be determined from those for the ions dissolving in the aqueous solution to evaluate the defect formation energies.

It is noted that the electrochemical potential for an ionic species $\mathrm{M}^{2+}$ in a solution is expressed in terms of a standard chemical potential $\mu_{\mathrm{M}^{2+}}^{\circ}$, an activity $\left(a_{\mathrm{M}^{2+}}\right)$, and an inner potential of the solution $\phi_{\mathrm{aq}}$ as $^{29,30}$

$$
\bar{\mu}_{\mathrm{M}^{2+}, \mathrm{aq}}=\mu_{\mathrm{M}^{2+}, \mathrm{aq}}^{\circ}+k_{\mathrm{B}} T \ln a_{\mathrm{M}^{2+}}+2 \phi_{\mathrm{aq}},
$$

where $k_{\mathrm{B}}$ is the Boltzmann constant and $T$ is the temperature. The temperature of $298 \mathrm{~K}$ is used throughout the present study. Substituting Eq. (2) into Eq. (1) gives rise to the defect formation energy as

$$
\begin{aligned}
\Delta H_{\mathrm{f}}= & E_{\mathrm{T}}(\text { defective })-E_{\mathrm{T}}(\text { perfect })+\mu_{\mathrm{Ca}^{2+}, \mathrm{aq}}^{\circ}-\mu_{\mathrm{M}^{2+}, \mathrm{aq}}^{\circ} \\
& +k_{\mathrm{B}} T \ln \left(a_{\left.\mathrm{Ca}^{2+} / a_{\mathrm{M}^{2+}}\right) .}\right.
\end{aligned}
$$

The standard chemical potential terms $\mu_{\mathrm{Ca}^{2+}, \mathrm{aq}}^{\circ}$ and $\mu_{\mathrm{M}^{2+}, \mathrm{aq}}^{\circ}$ are obtained by invoking chemical reactions to form the ionic species in aqueous solution in the standard state. For $\mathrm{Ca}^{2+}$, the following reaction,

$$
\mathrm{Ca}(\mathrm{s}) \rightarrow \mathrm{Ca}^{2+}\left(\mathrm{aq}, a_{\mathrm{Ca}^{2+}}=1\right)+2 \mathrm{e}^{-},
$$

is considered, and then $\mu_{\mathrm{Ca}^{2+}, \mathrm{aq}}^{\circ}$ is expressed by using the Gibbs energy change for the reaction $\Delta G_{\mathrm{f}}^{\circ}\left(\mathrm{Ca}^{2+}\right.$, aq $)$ as

$$
\mu_{\mathrm{Ca}^{2+}, \mathrm{aq}}^{\circ}=\Delta G_{\mathrm{f}}^{\circ}\left(\mathrm{Ca}^{2+}, \mathrm{aq}\right)+\mu_{\mathrm{Ca}, \mathrm{s}}^{\circ}-2 \mu_{\mathrm{e}^{-}, \mathrm{aq}}^{\circ} .
$$

Likewise, $\mu_{\mathrm{M}^{2+} \text {,aq }}^{\circ}$ can be obtained, and thus the chemical potential difference in Eq. (3) is given by

$$
\begin{aligned}
\mu_{\mathrm{Ca}^{2+}, \mathrm{aq}}^{\circ}-\mu_{\mathrm{M}^{2+}, \mathrm{aq}}^{\circ}= & \Delta G_{\mathrm{f}}^{\circ}\left(\mathrm{Ca}^{2+}, \mathrm{aq}\right)-\Delta G_{\mathrm{f}}^{\circ}\left(\mathrm{M}^{2+}, \mathrm{aq}\right) \\
& +\mu_{\mathrm{Ca}, \mathrm{s}}^{\circ}-\mu_{\mathrm{M}, \mathrm{s}}^{\circ} .
\end{aligned}
$$

The last two terms of the right-hand side of Eq. (6) correspond to the chemical potentials of pure metallic $\mathrm{Ca}$ and $\mathrm{M}$. In this study, total energies per atoms for bcc $\mathrm{Ca}$ and hcp $\mathrm{Mg}$ and $\mathrm{Zn}$ are separately calculated in the first-principles manner and are used for $\mu_{\mathrm{Ca}, \mathrm{s}}^{\circ}$ and $\mu_{\mathrm{M}, \mathrm{s}}^{\circ}$. In contrast, in order to obtain $\Delta G_{\mathrm{f}}^{\circ}\left(\mathrm{Ca}^{2+}\right.$, aq $)$ and $\Delta G_{\mathrm{f}}^{\circ}\left(\mathrm{M}^{2+}\right.$,aq $)$ by the firstprinciples method, it is necessary to calculate the ions dissolving in the aqueous solution. However, such calculations are not always easy to perform because of the complexity of the hydrated atomic structures in an aqueous solution. Since the standard Gibbs formation energies for ions in aqueous solution (at $298 \mathrm{~K}$ ) can be found in the thermodynamic table,${ }^{31}$ therefore, the experimental data are used for the quantities in this case.

The ionic activities of $a_{\mathrm{Ca}^{2+}}$ and $a_{\mathrm{M}^{2+}}$ in Eq. (3) comprise activity coefficients $\gamma$ and concentrations of the ionic species
$\left(\left[\mathrm{Ca}^{2+}\right]\right.$ and $\left.\left[\mathrm{M}^{2+}\right]\right)$ in the solution (e.g., $a_{\mathrm{M}^{2+}}=\gamma_{\mathrm{M}^{2+}}\left[\mathrm{M}^{2+}\right]$ ). In order to evaluate the activity of the ions in the solution, the following situations are assumed in this study: (a) the activity coefficients are assumed to be unity because the HApsaturated solution is basically a dilute one due to the small solubility product of $\mathrm{HAp}^{25}$ (b) the $\mathrm{M}^{2+}$ ions of particular concentrations are introduced into the solution by addition of $\mathrm{MA}_{2}$ compounds (e.g., $\mathrm{A}^{-}=\mathrm{NO}_{3}{ }^{-}$), as encountered in the previous experiments, ${ }^{6,732}$ (c) the solution $\mathrm{pH}$ is adjusted by adding acid $\mathrm{HX}$ in the low $\mathrm{pH}$ range and base $\mathrm{BOH}$ in the high $\mathrm{pH}$ range, ${ }^{33}$ and (d) the $\mathrm{A}^{-}, \mathrm{B}^{+}$, and $\mathrm{X}^{-}$ions are indifferent ions to dissolution equilibrium of HAp. As a result, in the low $\mathrm{pH}$ range, the charge neutrality condition of the solution can be written as

$$
\begin{aligned}
& 2\left[\mathrm{Ca}^{2+}\right]+2\left[\mathrm{M}^{2+}\right]+\left[\mathrm{H}^{+}\right] \\
&=\left[\mathrm{A}^{-}\right]+\left[\mathrm{X}^{-}\right]+\left[\mathrm{OH}^{-}\right]+3\left[\mathrm{PO}_{4}{ }^{3-}\right]+2\left[\mathrm{HPO}_{4}{ }^{2-}\right] \\
&+\left[\mathrm{H}_{2} \mathrm{PO}_{4}^{-}\right],
\end{aligned}
$$

where

$$
2\left[\mathrm{M}^{2+}\right]=\left[\mathrm{A}^{-}\right]
$$

and

$$
\left[\mathrm{H}^{+}\right]=\left[\mathrm{X}^{-}\right] .
$$

It is noted here that the phosphate ions have three different protonated forms, $\mathrm{HPO}_{4}{ }^{2-}, \mathrm{H}_{2} \mathrm{PO}_{4}^{-}$, and $\mathrm{H}_{3} \mathrm{PO}_{4}$ in the solution, depending on the solution $\mathrm{pH}$. In a similar way, the charge neutrality in the high $\mathrm{pH}$ range is described as

$$
\begin{aligned}
& 2\left[\mathrm{Ca}^{2+}\right]+2\left[\mathrm{M}^{2+}\right]+\left[\mathrm{H}^{+}\right]+\left[\mathrm{B}^{+}\right] \\
&=\left[\mathrm{A}^{-}\right]+\left[\mathrm{OH}^{-}\right]+3\left[\mathrm{PO}_{4}{ }^{3-}\right]+2\left[\mathrm{HPO}_{4}{ }^{2-}\right] \\
&+\left[\mathrm{H}_{2} \mathrm{PO}_{4}^{-}\right],
\end{aligned}
$$

where the following relation is imposed, together with Eq. (8);

$$
\left[\mathrm{B}^{+}\right]=\left[\mathrm{OH}^{-}\right] .
$$

In addition to the above charge neutrality requirements, the ionic product of water, the solubility product of HAp, ${ }^{34}$ and the three different acid dissociation constants for phosphate ions $\left(\mathrm{HPO}_{4}{ }^{2-}=\mathrm{PO}_{4}{ }^{3-}+\mathrm{H}^{+}, \mathrm{H}_{2} \mathrm{PO}_{4}{ }^{-}=\mathrm{HPO}_{4}{ }^{2-}+\mathrm{H}^{+}\right.$, and $\mathrm{H}_{3} \mathrm{PO}_{4}=\mathrm{H}_{2} \mathrm{PO}_{4}^{-}+\mathrm{H}^{+}$) are used to calculate the ionic concentration of $\mathrm{Ca}^{2+}$ as a function of the solution $\mathrm{pH}$. More details can also be found elsewhere. ${ }^{35}$ Figure 2 displays the calculated $\mathrm{pH}$ dependence of $\mathrm{Ca}^{2+}$ concentration in the HApsaturated aqueous solution. It can be seen that the $\mathrm{Ca}^{2+}$ concentration tends to increase with decreasing $\mathrm{pH} .{ }^{33}$ When the $\mathrm{pH}$ condition and the $\left[\mathrm{M}^{2+}\right]$ value of the solution are given, therefore, the defect formation energy for the ion substitution can be obtained as a function of $\mathrm{pH}$.

\section{RESULTS AND DISCUSSION}

\section{A. Electronic structure of bulk HAp and OCP}

Before going to ion substitution in HAp and OCP, electronic structures of perfect HAp and OCP lattices are investigated. Figure 3 shows total densities of states (DOS) for the valence bands (VBs) of HAp and OCP. As found in the pre- 


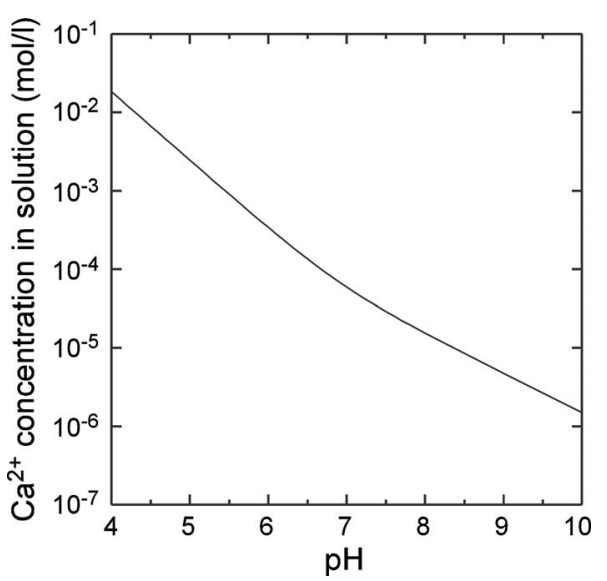

FIG. 2. $\mathrm{pH}$ dependence of $\mathrm{Ca}^{2+}$ concentration in the aqueous solution saturated with respect to HAp.

vious reports, the VB structure of HAp was described in detail, ${ }^{15,36,37}$ and thus a number of characteristics in the VB are briefly summarized here. The lower VB of HAp is composed of $\mathrm{O}-2 s$ and $\mathrm{Ca}-3 p$ orbitals, while $\mathrm{O}-2 p$ orbitals are a main component of the upper VB. The conduction band comprises $\mathrm{Ca}-3 d$ and $4 s$ orbitals, and the theoretical band gap of $5.3 \mathrm{eV}$ agrees with the previous theoretical data. ${ }^{36,37} \mathrm{It}$ is also noted that the upper VB exhibits four prominent peaks, which arise mainly from strong admixture between $\mathrm{P}-3 s p$ and $\mathrm{O}-2 s p$ orbitals in the energy range of -8 to $-4 \mathrm{eV}$ and from overlap of $\mathrm{Ca}-3 d 4 s$ and $\mathrm{O}-2 p$ orbitals in the range of $-4-0 \mathrm{eV} .^{15}$

The band gap for OCP is calculated to be $4.9 \mathrm{eV}$, which is slightly smaller than that of HAp, and the overall DOS
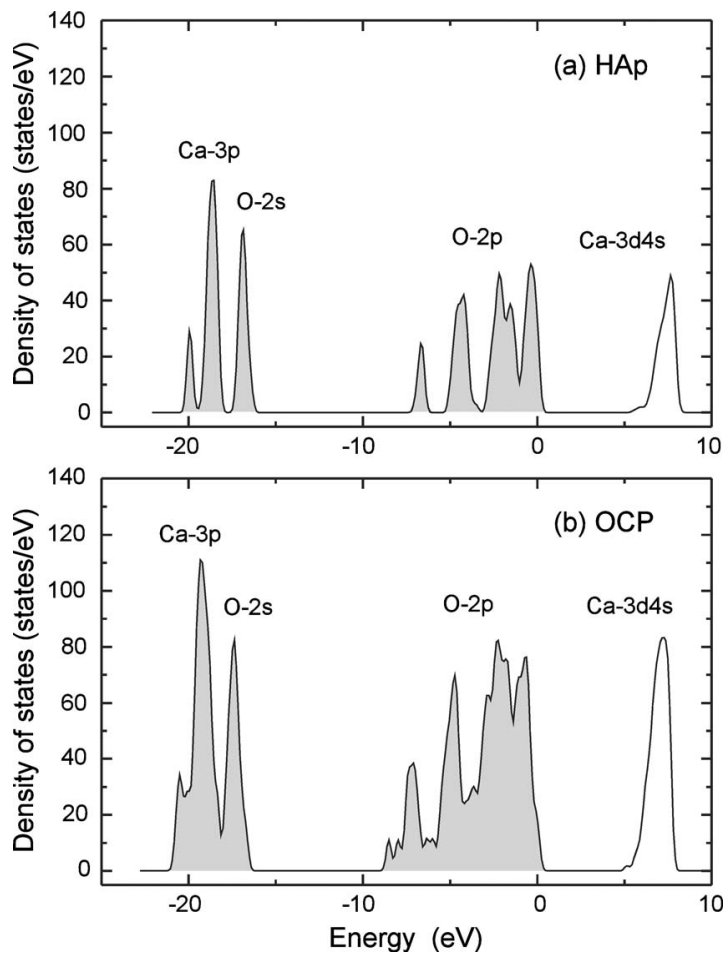

FIG. 3. Total DOS curves for perfect HAp and OCP. The shaded areas indicate the upper and lower VBs occupied by electrons. The VB maximum is set at $0 \mathrm{eV}$.
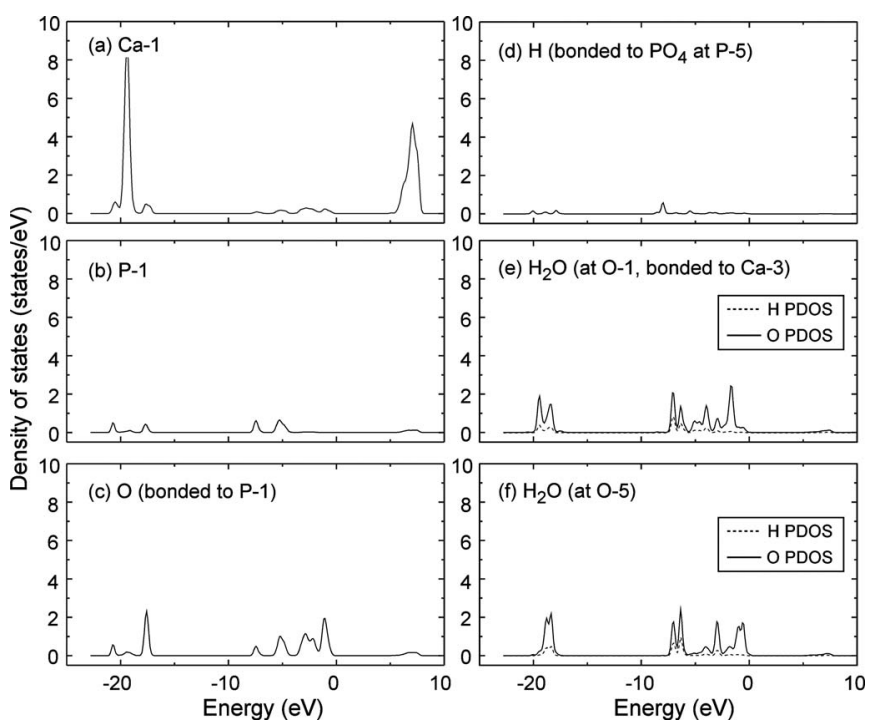

FIG. 4. Atom-projected partial DOS curves for constituent atoms in OCP.

feature is similar to that for HAp. The only difference in DOS from HAp is that small DOS components are observed between two neighboring peaks of the four prominent ones in the upper VB. This is mainly because OCP contains $\mathrm{HPO}_{4}$ groups and $\mathrm{H}_{2} \mathrm{O}$ molecules in its unit-cell structure, which are not found in HAp. In fact, it can be seen from the partial DOS curves in Fig. 4 that the energy levels originating from the proton of $\mathrm{HPO}_{4}$ (centered at $\mathrm{P}-5$ ) and the $\mathrm{H}_{2} \mathrm{O}$ molecules also lie in the same energy range with $\mathrm{O}-2 p$ components from $\mathrm{PO}_{4}$ groups in the apatitic layer. Such complexity of the unit-cell structure of OCP results in the slight difference in DOS between HAp and OCP.

\section{B. Atomic structures of substitutional magnesium and zinc in HAp}

In order to investigate structural characteristics around $\mathrm{Mg}^{2+}$ and $\mathrm{Zn}^{2+}$ in HAp, the calculated distances from the substitutional cations to the neighboring atoms are investigated. ${ }^{38}$ The coordination numbers of $\mathrm{Mg}^{2+}$ to oxygen within the first NN shell are 6 at both the Ca-1 and Ca-2 sites, as is the case in perfect HAp (see Table I). However, the bond distances from $\mathrm{Mg}^{2+}$ to the first $\mathrm{NN}$ oxygen atoms are by about $8.5 \%$ on average smaller than the nearest neighboring $\mathrm{Ca}-\mathrm{O}$ distances in the perfect lattice. This can be understood from the much smaller ionic radius of $\mathrm{Mg}^{2+}$ $(0.072 \mathrm{~nm})$ than that of $\mathrm{Ca}^{2+}(0.100 \mathrm{~nm})$ in the sixfold coordination. $^{39}$.

Since $\mathrm{Zn}^{2+}$ is also much smaller in size $(0.074 \mathrm{~nm})$ than $\mathrm{Ca}^{2+}, 39$ the similar inward relaxation of the first NN oxygen atoms can be found for $\mathrm{Zn}^{2+}$ substitution for $\mathrm{Ca}-1$, whereas the local atomic coordination of $\mathrm{Zn}^{2+}$ at the $\mathrm{Ca}-2$ site is quite different from the Ca-1 case. The interatomic distance from $\mathrm{Zn}^{2+}$ at the Ca-2 site to first NN oxygen is by about $13 \%$ shorter than that in the perfect lattice, and the resultant coordination number within the first NN shell becomes 4 . In fact, it can be seen in the relaxed geometry of Fig. 5 that the $\mathrm{OH}^{-}$ group adjacent to $\mathrm{Zn}^{2+}$ is significantly displaced from the $c$ axis toward $\mathrm{Zn}^{2+}$, where the $\mathrm{Zn}-\mathrm{OH}$ distance is $0.205 \mathrm{~nm}$. Since $\mathrm{Zn}$ atoms prefer to have fourfold coordination with 


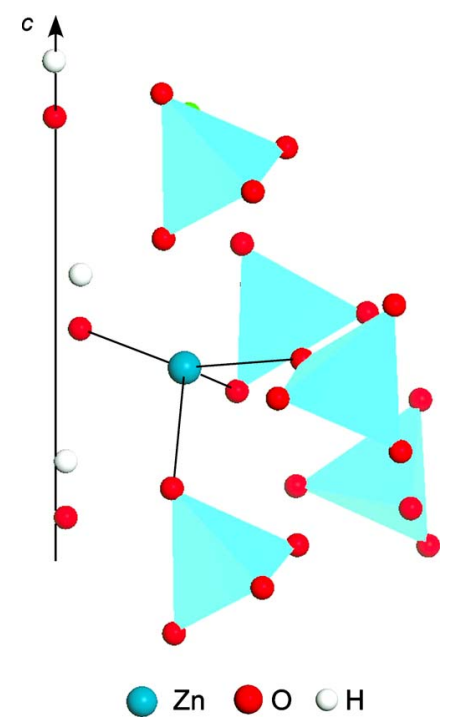

FIG. 5. (Color online) Optimized atomic structure around $\mathrm{Zn}^{2+}$ substituting for Ca-2 in HAp. The first NN oxygen atoms in the fourfold coordination state are shown by being connected with $\mathrm{Zn}^{2+}$ by the thin solid lines. The surrounding tetrahedra represent $\mathrm{PO}_{4}^{3-}$ groups.

oxygen as found in bulk $\mathrm{ZnO}$, it is thought that the $\mathrm{ZnO}_{4}$ tetrahedral configuration can also be formed depending on the substitutional sites in HAp. It seems likely that structural constraint at the $\mathrm{Ca}-2$ site is less than that at $\mathrm{Ca}-1$, due to the presence of the relatively mobile $\mathrm{OH}^{-}$group at the adjacent site.

Figures 6(a) and 6(b) display partial densities of states (PDOSs) of $\mathrm{Mg}^{2+}$ and $\mathrm{Zn}^{2+}$ in HAp. In this case, the PDOS curves of the first $\mathrm{NN}$ oxygen atoms are also plotted. As stated in Fig. 1, the upper VB in HAp is mainly composed of $\mathrm{O}-2 p$, and the $\mathrm{Mg}-3 s p$ orbitals only slightly contribute to the upper VB. This indicates a typical ionic character of bonding between $\mathrm{Mg}$ and the first NN oxygen in HAp. In Fig. 6(b), the $\mathrm{Zn}-3 d$ band is located at around $-5 \mathrm{eV}$, and also the $\mathrm{Zn}-4 s p$ orbitals more contribute to the upper VB, as compared to Mg-3sp in Fig. 6(a). Although Zn-3d orbitals are fully occupied by electrons [electronic configuration of $\left.3 d^{10}\right]$, the originally unoccupied $\mathrm{Zn}-4 s p$ orbitals overlap with $\mathrm{O}-2 p$ orbitals in a bonding manner, which results in covalent bond formation of $\mathrm{Zn}-\mathrm{O}$. This can also be observed in the contour maps of the charge densities for $\mathrm{Mg}^{2+}$ and $\mathrm{Zn}^{2+}$ at the Ca-2 site shown in Fig. 7. In the case of $\mathrm{Mg}^{2+}$ [Fig. 7(a)], the electron densities of $\mathrm{Mg}^{2+}$ and the adjacent oxygen of the $\mathrm{OH}^{-}$group exhibit slight overlap, which is quite similar to the electron densities around ionically bonded $\mathrm{Ca}-\mathrm{O}$. However, more electrons are accumulated between $\mathrm{Zn}^{2+}$ and $\mathrm{O}^{2-}$ in Fig. 7(b), as compared with the $\mathrm{Mg}^{2+}$ case. It can be thought, therefore, that $\mathrm{Zn}^{2+}$ at $\mathrm{Ca}-2$ tends to have the decreased coordination number of 4 so as to make the strong covalent bonds with $\mathrm{O}$ in the tetrahedral configuration.

\section{Atomic structures of magnesium and zinc substitution in OCP}

Atomic coordination structures for $\mathrm{Mg}^{2+}$ and $\mathrm{Zn}^{2+}$ in OCP are also investigated. ${ }^{38}$ As also stated in Table I, the $\mathrm{Ca}-\mathrm{O}$ bond lengths in perfect $\mathrm{OCP}$ exhibit the wide variation of $0.23-0.28 \mathrm{~nm}$. This is also the cases for $\mathrm{Mg}^{2+}$ and $\mathrm{Zn}^{2+}$ substitution. In order to define the first $\mathrm{NN}$ coordination shell for the substitutional defects, therefore, the radius of a $15 \%$ larger value $(0.24 \mathrm{~nm})$ of the interatomic distances of $\mathrm{Mg}-\mathrm{O}$ and $\mathrm{Zn}-\mathrm{O}$ in bulk $\mathrm{MgO}$ and $\mathrm{ZnO}$ (about $0.21 \mathrm{~nm}$ ) is used. ${ }^{38}$

The $\mathrm{Mg}-\mathrm{O}$ distances in OCP vary in the range of $0.20-0.24 \mathrm{~nm}$, which is by about $15 \%$ smaller than the $\mathrm{Ca}-\mathrm{O}$ lengths in bulk OCP. In addition, the coordination
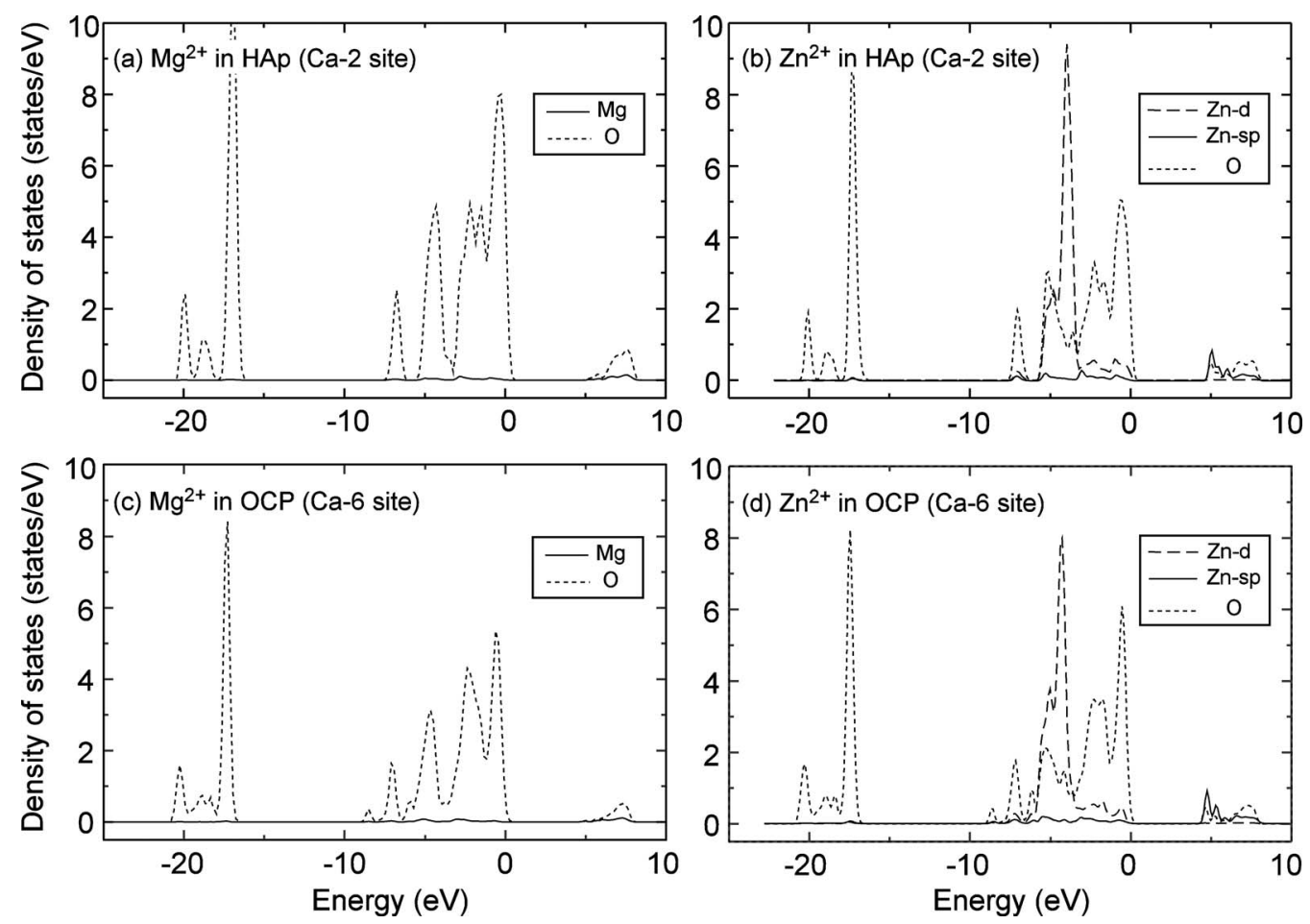

FIG. 6. Atom-projected PDOS curves for $\mathrm{Mg}^{2+}$ and $\mathrm{Zn}^{2+}$ in HAp and OCP. In the figures, the PDOS profiles of the first NN oxygen atoms are also depicted. 
(a)



(b)

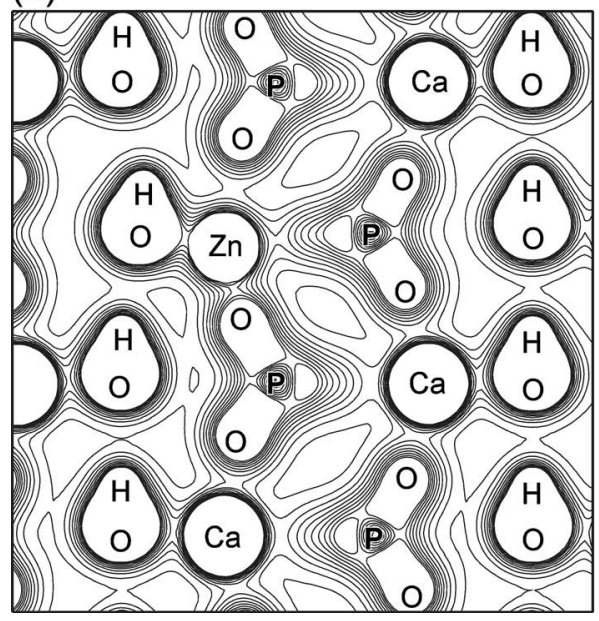

FIG. 7. Contour maps of electron densities around $\mathrm{Mg}^{2+}$ and $\mathrm{Zn}^{2+}$ at the Ca-2 site of HAp. The contour lines are drawn with an interval of 0.05 from 0.0 to 0.5 electrons $/ \AA^{3}$.

numbers of $\mathrm{Ca}$ to the first $\mathrm{NN} \mathrm{O}$ atoms are 6 or 7 in bulk OCP, whereas the $\mathrm{Mg}^{2+}$ ions at the $\mathrm{Ca}-2, \mathrm{Ca}-3, \mathrm{Ca}-4, \mathrm{Ca}-6$, and $\mathrm{Ca}-8$ sites in OCP are fivefold coordinated by the first $\mathrm{NN} \mathrm{O}$ atoms. The tendency of the decreased coordination numbers of $\mathrm{Mg}^{2+}$ is attributed to its small ionic radius and interactions between the surrounding oxygen ions. It can be imagined that, when the small-sized cation is incorporated at the large-sized $\mathrm{Ca}^{2+}$ site, the surrounding $\mathrm{O}^{2-}$ ions tend to move toward the cation due to the size difference. Simultaneously, however, the negatively charged $\mathrm{O}^{2-}$ ions come close to one another around $\mathrm{Mg}^{2+}$, which induces considerable electrostatic repulsion between the $\mathrm{O}^{2-}$ ions. In order to reduce energy penalty of the $\mathrm{O}^{2-}-\mathrm{O}^{2-}$ interactions, a number of $\mathrm{O}^{2-}$ ions move away from the cation site, so that the coordination numbers of $\mathrm{Mg}^{2+}$ with $\mathrm{O}^{2-}$ in OCP tend to decrease depending on the substitutional sites. Such considerable atomic relaxation may be allowed due to the low symmetry of the OCP structure.

In the case of $\mathrm{Zn}^{2+}$ in OCP, the similar decreases in the bond lengths and the coordination numbers with first $\mathrm{NN}$ oxygen can be observed. ${ }^{38}$ It should be noted, however, that the coordination numbers of $\mathrm{Zn}^{2+}$ in OCP are 4 or 5, depending on the atomic sites, which are smaller even compared

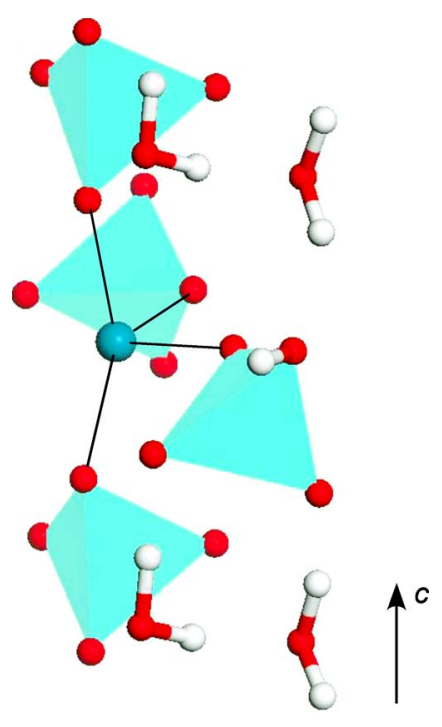

$\mathrm{Zn} \mathrm{OOOH}$

FIG. 8. (Color online) Optimized atomic structure of $\mathrm{Zn}^{2+}$ at the $\mathrm{Ca}-6$ site in OCP. The first NN oxygen atoms in the fourfold coordination state are shown by being connected with $\mathrm{Zn}^{2+}$ by the thin solid lines. The surrounding tetrahedra indicate $\mathrm{PO}_{4}^{3-}$ groups.

with those of $\mathrm{Mg}^{2+}$ (the fivefold or sixfold coordination). As an example, the optimized atomic structure of $\mathrm{Zn}^{2+}$ at $\mathrm{Ca}-6$ is displayed in Fig. 8. Since $\mathrm{Zn}$ in bulk $\mathrm{ZnO}$ has a smaller coordination number of 4 with oxygen than that of $\mathrm{Mg}$ in bulk $\mathrm{MgO}$ (sixfold coordinated), it can be expected that $\mathrm{Zn}^{2+}$ in OCP also tends to favor the fourfold coordination. Such a tendency can also be seen in the case of $\mathrm{Zn}^{2+}$ at the Ca-2 site of HAp (Fig. 5).

The PDOS curves of $\mathrm{Mg}^{2+}$ and $\mathrm{Zn}^{2+}$ at the Ca- 6 sites are plotted in Figs. 6(c) and 6(d). These results are quite similar to those in HAp [Figs. 6(a) and 6(b)], where the Zn-4sp orbital components more contribute to the upper VB comprising $\mathrm{O}-2 p$ orbitals, as compared to the $\mathrm{Mg}^{2+}$ case. It can be said, therefore, that the $\mathrm{Zn}^{2+}$ ion substituting for $\mathrm{Ca}$ is stabilized by covalent interactions with the surrounding $\mathrm{O}$ atoms at the expense of the decreased coordination numbers.

\section{Thermodynamic stability of substitutional magnesium and zinc}

As shown above, substituted $\mathrm{Mg}^{2+}$ and $\mathrm{Zn}^{2+}$ ions for $\mathrm{Ca}$ in HAp and OCP tend to have the smaller coordination numbers with oxygen, and the covalent bonds are formed especially in the $\mathrm{Zn}^{2+}$ substitution case. In this subsection, the thermodynamic stability of the substitutional defects is evaluated, and the difference between HAp and OCP as well as the site dependence is investigated.

Figure 9 shows the formation energies of substitutional $\mathrm{Mg}^{2+}$ and $\mathrm{Zn}^{2+}$ in HAp and OCP as a function of $\mathrm{pH}$. Here, the energies are obtained by assuming the chemical equilibrium with the HAp-saturated solution in which the $\mathrm{Mg}^{2+}$ or $\mathrm{Zn}^{2+}$ concentration is set at $1.0 \times 10^{-3} \mathrm{~mol} / 1$ as found in physicological conditions.

As a general trend, it can be seen that the formation energies tend to increase with decreasing $\mathrm{pH}$. This tendency 

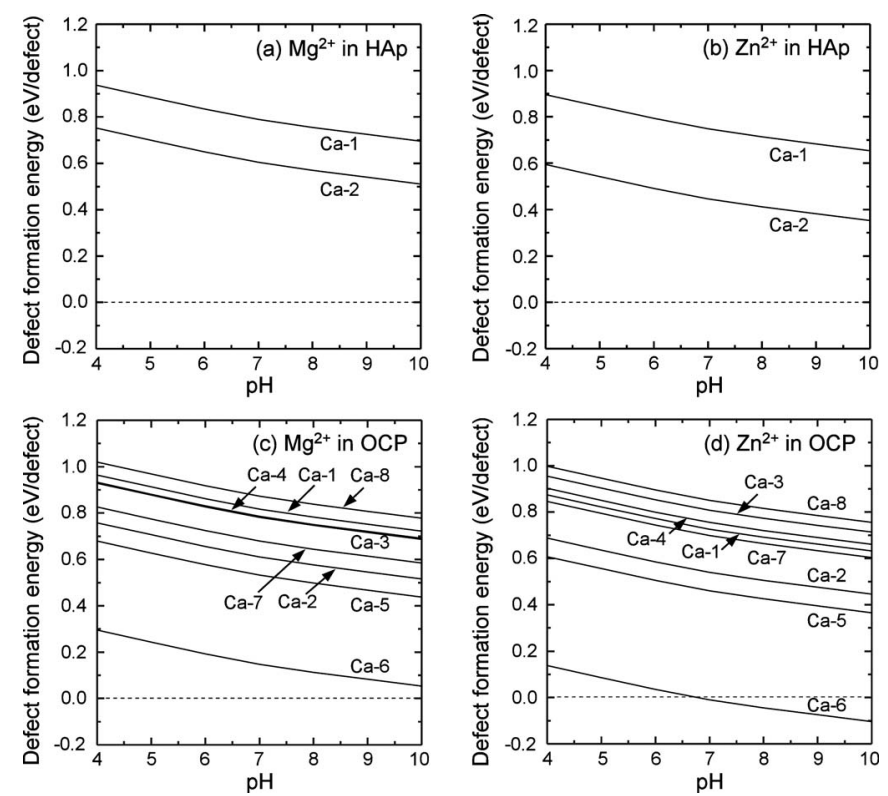

FIG. 9. Defect formation energies of substitutional $\mathrm{Mg}^{2+}$ and $\mathrm{Zn}^{2+}$ in $\mathrm{HAp}$ and $\mathrm{OCP}$ as a function of $\mathrm{pH}$. In this case, the results are obtained by assuming the ionic concentrations of $\mathrm{Mg}^{2+}$ and $\mathrm{Zn}^{2+}$ in the solution to be $1.0 \times 10^{-3} \mathrm{~mol} / 1$

is attributed to variations of chemical potentials for $\mathrm{Ca}^{2+}$ in Eq. (1) against the solution pH. As can be seen in Fig. 2, the $\mathrm{Ca}^{2+}$ concentration (activity) in the solution increases with lowering $\mathrm{pH}$. In such a low $\mathrm{pH}$ range, $\mathrm{Ca}^{2+}$ release from HAp or OCP into the solution by exchange with $\mathrm{M}^{2+}$ is difficult to occur, which results in the increase in formation energies of the substitutional defects with smaller $\mathrm{pH}$.

For $\mathrm{Mg}^{2+}$ and $\mathrm{Zn}^{2+}$ in HAp [Figs. 9(a) and 9(b)], it is found that the formation energies for substitutional $\mathrm{Zn}^{2+}$ are smaller than those of the $\mathrm{Mg}^{2+}$ case. This tendency is consistent with the experimental trend reported by Suzuki et al. showing the much larger ion-exchange ability for $\mathrm{Zn}^{2+}$ in HAp than for $\mathrm{Mg}^{2+} \cdot{ }^{32}$ As stated in Fig. 6, $\mathrm{Zn}^{2+}$ is more covalently bonded to the surrounding oxygen in HAp, which is thought to be the main reason of the relative stability of the two substitutional cations. Moreover, in both the $\mathrm{Mg}^{2+}$ and $\mathrm{Zn}^{2+}$ cases, the replacement at the Ca-2 site is energetically more favorable than that at the $\mathrm{Ca}-1$ site. Regarding the site preference of different-sized foreign cations substituting for the two Ca sites in HAp, Elliot discussed a spatial difference between the two $\mathrm{Ca}$ sites in the original HAp lattice. If the coordination numbers of the Ca sites within the second NN coordination shell of perfect HAp are considered, ${ }^{25}$ the Ca-1 site is in the ninefold coordination with oxygen, whereas the $\mathrm{Ca}-2$ site has the sevenfold coordination. In general, largersized cations tend to have a larger coordination number with the surrounding anions to form more ionic bonds, while smaller-sized cations prefer to occupy smaller coordination sites so as to reduce electrostatic repulsion between the surrounding anions. Also, the average $\mathrm{Ca}-\mathrm{O}$ length for $\mathrm{Ca}-1$ of $0.257 \mathrm{~nm}$ is larger than that for Ca-2 $(0.247 \mathrm{~nm})$. Based on this simple geometrical consideration, it is expected that the smaller-sized $\mathrm{Mg}^{2+}$ and $\mathrm{Zn}^{2+}$ prefer to occupy the Ca-2 site in HAp. It is noted that the preference of the $\mathrm{Ca}-2$ site for
$\mathrm{Zn}^{2+}$ substitution in HAp is consistent with the firstprinciples result by $\mathrm{Ma}$ and Ellis, although they treated the substitution on the HAp (0001) surface. ${ }^{19}$

When $\mathrm{Mg}^{2+}$ and $\mathrm{Zn}^{2+}$ are incorporated in OCP [Figs. 9(c) and 9(d)], they have the formation energies at most of the Ca sites similar to those in HAp. It can be seen, however, that the formation energies at the Ca- 6 site become considerably small for both $\mathrm{Mg}^{2+}$ and $\mathrm{Zn}^{2+}$, as compared to those at the other $\mathrm{Ca}$ sites. This can also be explained by the geometrical consideration for the Ca sites in OCP. As also stated in the HAp case, since $\mathrm{Mg}^{2+}$ and $\mathrm{Zn}^{2+}$ are much smaller in size than $\mathrm{Ca}^{2+}$, it is expected that they can easily occupy the $\mathrm{Ca}$ sites having the smaller coordination numbers with oxygen. As can be seen in Table I, the lower coordinated $\mathrm{Ca}$ sites (sixfold) in the original OCP lattice correspond to $\mathrm{Ca}-3$, Ca-5, Ca-6, and Ca-8. Among them, the average bond length of $\mathrm{Ca}-\mathrm{O}$ at the $\mathrm{Ca}-6$ site is the smallest $(0.240 \mathrm{~nm})$, which indicates that $\mathrm{Ca}-6$ is a plausible substitutional site for smallsized $\mathrm{Mg}^{2+}$ and $\mathrm{Zn}^{2+}$. It is noted that the Ca-5 site is also sixfold coordinated by oxygen with the average bond length of $0.241 \mathrm{~nm}$, which is quite similar to Ca-6. In fact, it is found in Fig. 9 that the substitution at the $\mathrm{Ca}-5$ site also shows the relatively smaller formation energies than the other substitution cases except for Ca-6.

It is also worth mentioning here that $\mathrm{Zn}^{2+}$ at $\mathrm{Ca}-6$ exhibits the smaller formation energy than $\mathrm{Mg}^{2+}$ at $\mathrm{Ca}-6$. The formation energy of $\mathrm{Zn}^{2+}$ at $\mathrm{Ca}-6$ becomes negative above neutral $\mathrm{pH}$. It can be said that $\mathrm{Zn}^{2+}$ can completely replace $\mathrm{Ca}^{2+}$ ions at the $\mathrm{Ca}-6$ site of OCP in the neutral and alkaline aqueous conditions.

Based on the calculated formation energies of substitutional $\mathrm{Mg}^{2+}$ and $\mathrm{Zn}^{2+}$ in HAp and OCP, their equilibrium concentrations $C_{\mathrm{M}^{2+}}$ are evaluated. Then, the following equation is employed:

$$
C_{\mathrm{M}^{2+}}=\exp \left(-\frac{\Delta H_{\mathrm{f}}}{k_{\mathrm{B}} T}\right) .
$$

As shown in Fig. 9, the formation energies strongly depend on the substitutional sites. Therefore, the site occupancies of the substitutional ions are individually calculated for all the Ca sites in HAp and OCP, and are summed up to evaluate the concentrations of substitutional $\mathrm{Mg}^{2+}$ and $\mathrm{Zn}^{2+}$ in the respective crystals.

Figure 10 displays the equilibrium concentrations of $\mathrm{Mg}^{2+}$ and $\mathrm{Zn}^{2+}$ in HAp and OCP against $\mathrm{pH}$ of the surrounding solution (at $298 \mathrm{~K}$ ). Since the defect formation energies also depend on the ionic contents of $\mathrm{Mg}^{2+}$ and $\mathrm{Zn}^{2+}$ in the solution $\left[\mathrm{M}^{2+}\right]$, the results for $\left[\mathrm{M}^{2+}\right]=1.0 \times 10^{-4} \mathrm{~mol} / 1$ are also plotted for comparison.

In this figure, it is noted that the results of $\mathrm{Mg}^{2+}$ and $\mathrm{Zn}^{2+}$ in HAp cannot be observed. This is because the evaluated defect concentrations in HAp at $298 \mathrm{~K}$ are less than $10^{-6}$ at. $\%$ due to the relatively large formation energies [see Figs. 9(a) and 9(b)]. This indicates that $\mathrm{Mg}^{2+}$ and $\mathrm{Zn}^{2+}$ substitution for $\mathrm{Ca}^{2+}$ is quite difficult to take place in the HAp structure.

Regarding the solubility of $\mathrm{Mg}^{2+}$ and $\mathrm{Zn}^{2+}$ in HAp, contradictory data were experimentally reported. Pantel indicated that $\mathrm{Mg}^{2+}$ can be incorporated in HAp to form the solid 


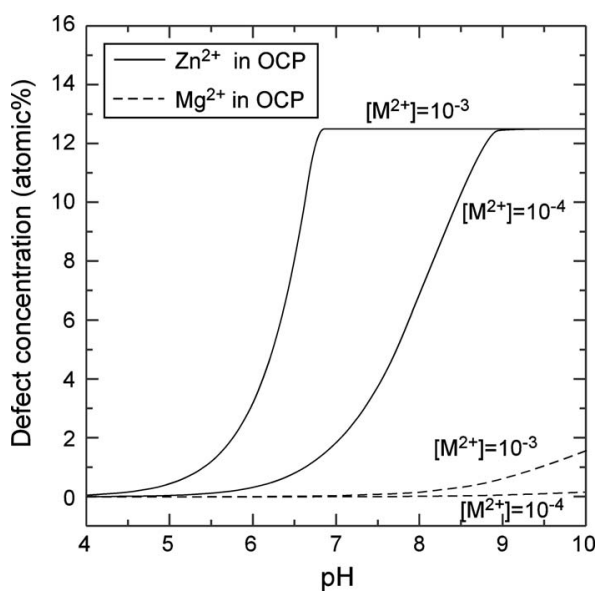

FIG. 10. Equilibrium concentrations of the substitutional defects as a function of $\mathrm{pH}$. Here only the results for OCP can be observed because of the much smaller defect concentrations in HAp.

solution, ${ }^{40}$ whereas Neuman and Muhyan ${ }^{41}$ and Bigi et al. ${ }^{6}$ showed that most of $\mathrm{Mg}^{2+}$ ions in the HAp-solution system cannot be incorporated inside HAp crystals and are limited to be loosely bound at HAp surfaces. LeGeros also suggested a quite limited replacement of $\mathrm{Ca}^{2+}$ by $\mathrm{Mg}^{2+}$ in HAp. ${ }^{42}$ More recently, Kannan et al. reported magnesium incorporation in mixtures of HAp and $\beta$-TCP but there is no indication of $\mathrm{Mg}^{2+}$ substitution in the HAp lattice. ${ }^{43}$ Likewise, formation of zinc-calcium HAp solid solution was also reported, ${ }^{44}$ and yet Bigi et l. $^{7}$ later indicated the difficulty of $\mathrm{Zn}^{2+}$ incorporation into HAp. Miyaji et al. showed that the substituting limit of $\mathrm{Zn}$ in synthetic HAp is about $15 \mathrm{~mol} \%{ }^{45}$ In this regard, the present results show the extreme difficulty of $\mathrm{Mg}^{2+}$ and $\mathrm{Zn}^{2+}$ incorporation in HAp. In addition, it is known that $\mathrm{Mg}^{2+}$ and $\mathrm{Zn}^{2+}$ added in the aqueous solution inhibit HAp crystallization and destabilize the HAp crystalline phase. ${ }^{6,7}$ This may also imply that the incorporation of $\mathrm{Mg}^{2+}$ and $\mathrm{Zn}^{2+}$ in HAp is essentially not energetically favorable.

In contrast, it can be seen that OCP can accept much more substitutional $\mathrm{Mg}^{2+}$ and $\mathrm{Zn}^{2+}$, depending on the surrounding $\mathrm{pH}$ condition, and that $\mathrm{Zn}^{2+}$ is more incorporated in $\mathrm{OCP}$, as compared to $\mathrm{Mg}^{2+}$. The substitutional $\mathrm{Zn}^{2+}$ concentration in OCP readily increases with increasing $\mathrm{pH}$. In the case of $\left[\mathrm{M}^{2+}\right]=1.0 \times 10^{-3} \mathrm{~mol} / 1, C_{\mathrm{Zn}^{2+}}$ is saturated at 12.5 at. $\%$, which corresponds to the fully substituted Ca-6 site by $\mathrm{Zn}^{2+}$ in OCP. In fact, it is observed in Fig. 9 that the formation energy of $\mathrm{Zn}^{2+}$ at Ca- 6 becomes zero at around neutral $\mathrm{pH}$. Since the formation energies at the other Ca sites exhibit larger values than that at $\mathrm{Ca}-6$, the $\mathrm{Zn}^{2+}$ concentrations at the $\mathrm{Ca}$ sites except for $\mathrm{Ca}-6$ are actually negligible. In contrast, the $\mathrm{Mg}^{2+}$ concentration in OCP around neutral $\mathrm{pH}$ is much smaller than the $\mathrm{Zn}^{2+}$ case, which can be understood from the larger formation energy of $\mathrm{Mg}^{2+}$ at $\mathrm{Ca}-6$ shown in Fig. 9(c).

Based on the present results, it can be said that the biological effects of $\mathrm{Mg}^{2+}$ and $\mathrm{Zn}^{2+}$ to enhance bone formation cannot be directly related to their incorporation into HAp crystals. Since $\mathrm{Zn}^{2+}$ can be easily incorporated in OCP by exchange with $\mathrm{Ca}^{2+}$, however, it can be expected that $\mathrm{Zn}^{2+}$ play its biological role by being located at the low-crystalline transition region on HAp crystals. In this case, it may be speculated that $\mathrm{Zn}^{2+}$ directly promotes adsorption and activity of osteoblast cells at the transition region, which may contribute to the enhanced bone formation. In contrast, $\mathrm{Mg}^{2+}$ is much more difficult to substitute for $\mathrm{Ca}$ even in OCP. Since hard tissues such as bone and tooth is a mixture of apatite minerals and organic components of collagen and water, most of $\mathrm{Mg}^{2+}$ may be located in the organic part or in the surrounding body fluid. If this is the case, $\mathrm{Mg}^{2+}$ ions are readily available to directly act on cells and enzyme to promote bone formation. ${ }^{13}$

It is finally noted that the present study dealt with the single substitution of $\mathrm{Mg}^{2+}$ and $\mathrm{Zn}^{2+}$ for $\mathrm{Ca}^{2+}$ in the perfect lattices of HAp and OCP. As a matter of fact, biological HAp also contains a certain amount of other foreign cations and anions, and, in particular, the carbonate $\left(\mathrm{CO}_{3}{ }^{2-}\right)$ content is much larger than those of all the other impurities, ${ }^{1}$ which will affect the solubility of other trace elements. In this regard, Tas reported that, when HAp powders are precipitated in simulated body fluid (SBF) solution, $\mathrm{Mg}^{2+}$ and $\mathrm{CO}_{3}{ }^{2-}$ ions coming from the SBF are favorably incorporated in the powders. ${ }^{46}$ This is an indication of cosubstitution of the ions in HAp, which should be further addressed in future.

\section{CONCLUSIONS}

In this study, first-principles calculations are performed for $\mathrm{Mg}^{2+}$ and $\mathrm{Zn}^{2+}$ substitution in HAp and OCP, in order to reveal their possible location in the system of HAp in contact with the aqueous solution. OCP is assumed to be a structural model of the transition region between HAp and the solution. Owing to the smaller ionic sizes of $\mathrm{Mg}^{2+}$ and $\mathrm{Zn}^{2+}$ than $\mathrm{Ca}^{2+}$, the substitution for $\mathrm{Ca}$ sites of HAp and OCP brings about considerable inward atomic relaxation of the surrounding oxygen ions, which results in the smaller coordination numbers with oxygen as compared with that of $\mathrm{Ca}$ in bulk HAp and OCP. It is also found that the substitutional $\mathrm{Zn}^{2+}$ ions tend to form the covalent bonds with oxygen in the fourfold coordination state.

From the calculated defect formation energies, it is likely that the substitutional foreign ions are quite difficult to dissolve into HAp whereas can be more easily incorporated in OCP. In particular, $\mathrm{Zn}^{2+}$ can more favorably substitute for the specific Ca site of OCP, as compared to $\mathrm{Mg}^{2+}$, due to the covalent character of bonding.

\section{ACKNOWLEDGMENTS}

This study was supported by Grant-in-Aid for Scientific Research on Priority Areas "Nano Materials Science for Atomic Scale Modification 474" from Ministry of Education, Culture, Sports, Science and Technology (MEXT) of Japan. The author also acknowledges I. Tanaka for his support of computation.

\footnotetext{
${ }^{1}$ S. V. Dorozhkin, J. Mater. Sci. 42, 1061 (2007).

${ }^{2}$ R. K. Rude, H. E. Gruber, L. Y. Wei, A. Frausto, and B. G. Mills, Calcif. Tissue Int. 72, 32 (2003).

${ }^{3}$ H. Kawamura, A. Ito, S. Miyakawa, P. Layrolle, K. Ojima, N. Ichinose, and T. Tateishi, J. Biomed. Mater. Res. 50, 184 (2000).
} 
${ }^{4}$ S. Hayakawa, K. Ando, K. Tsuru, A. Osaka, E. Fujii, and K. Kawabata, J. Am. Ceram. Soc. 90, 565 (2007).

${ }^{5}$ A. Bigi, E. Foresti, R. Gregorini, A. Ripamonti, N. Roveri, and J. S. Shah, Calcif. Tissue Int. 50, 439 (1992).

${ }^{6}$ A. Bigi, G. Falini, E. Foresti, M. Grazzano, A. Ripamonti, and N. Roveri, J. Inorg. Biochem. 49, 69 (1993).

${ }^{7}$ A. Bigi, E. Foresti, M. Gandolfi, M. Grazzano, and N. Roveri, J. Inorg. Biochem. 58, 49 (1995).

${ }^{8}$ N. Kanzaki, K. Onuma, G. Treboux, S. Tsutsumi, and A. Ito, J. Phys. Chem. B 104, 4189 (2000).

${ }^{9}$ W. E. Brown and L. C. Chow, Colloids Surf. 7, 67 (1983).

${ }^{10}$ M. S. Tung and D. Skrtic, in Octacalcium Phosphate, Monograph Oral Science Vol. 18, edited by L. C. Chow and E. D. Eanes (Basel, Karger, 2001), p. 112.

${ }^{11}$ M. S. A. Johnsson and G. H. Nancollas, Crit. Rev. Oral Biol. Med. 3, 61 (1992).

${ }^{12}$ R. A. Santos, R. A. Wind, and C. E. Bronnimann, J. Magn. Reson., Ser. B 105, 183 (1994).

${ }^{13}$ S. Cazalbou, D. Eichert, X. Ranz, C. Drouet, C. Combes, M. F. Harmand, and C. Rey, J. Mater. Sci. 16, 405 (2005).

${ }^{14}$ W. E. Brown, M. Mathew, and M. S. Tung, Prog. Cryst. Growth Charact. 4, 59 (1981).

${ }^{15}$ K. Matsunaga and A. Kuwabara, Phys. Rev. B 75, 014102 (2007).

${ }^{16}$ P. Rulis, H. Yao, L. Ouyang, and W. Y. Ching, Phys. Rev. B 76, 245410 (2007).

${ }^{17}$ J. Terra, M. Jiang, and D. E. Ellis, Philos. Mag. A 82, 2357 (2003).

${ }^{18}$ X. Yin, L. Calderin, M. J. Stott, and M. Sayer, Biomaterials 23, 4155 (2002).

${ }^{19}$ X. Ma and D. E. Ellis, Biomaterials 29, 257 (2008).

${ }^{20}$ G. Kresse and J. Furthmüller, Phys. Rev. B 54, 11169 (1996)

${ }^{21}$ P. E. Blöchl, Phys. Rev. B 50, 17953 (1994).

${ }^{22}$ G. Kresse and D. Joubert, Phys. Rev. B 59, 1758 (1999).

${ }^{23}$ J. P. Perdew, K. Burke, and M. Ernzerhof, Phys. Rev. Lett. 77, 3865 (1996).

${ }^{24}$ M. I. Kay, R. A. Young, and A. S. Posner, Nature (London) 204, 1050 (1964).
${ }^{25}$ J. C. Elliot, Structure and Chemistry of the Apatites and Other Calcium Orthophosphates (Elsevier, Amsterdam, 1994).

${ }^{26}$ M. Mathew, W. E. Brown, and L. W. Schroeder, J. Crystallogr. Spectrosc. Res. 18, 235 (1988).

${ }^{27}$ C. A. Beevers, Acta Crystallogr. 11, 273 (1958).

${ }^{28}$ H. J. Monkhorst and J. D. Pack, Phys. Rev. B 13, 5188 (1976).

${ }^{29}$ J. R. Pliego, Jr. and J. M. Riveros, Chem. Phys. Lett. 332, 597 (2000).

${ }^{30}$ J. Llano and L. A. Eriksson, J. Chem. Phys. 117, 10193 (2002).

${ }^{31}$ D. D. Wagman, W. H. Evans, V. B. Parker, R. H. Schumm, I. Halow, S. M. Bailey, K. L. Churney, and R. L. Nuttall, The NBS Tables of Chemical Thermodynamic Properties, J. Phys. Chem. Ref. Data 11, 1 (1982).

${ }^{32}$ T. Suzuki, T. Hatsushika, and Y. Hayakawa, J. Chem. Soc., Faraday Trans. 1 77, 1059 (1981).

${ }^{33}$ S. Chander and D. W. Fuerstenau, J. Colloid Interface Sci. 70, 506 (1979).

${ }^{34}$ R. M. H. Verbeeck, H. Steyaert, H. P. Thun, and F. Verbeek, J. Chem. Soc., Faraday Trans. 1 76, 209 (1980).

${ }^{35}$ K. Matsunaga, Phys. Rev. B 77, 104106 (2008)

${ }^{36}$ L. Calderin, M. J. Stott, and A. Rubio, Phys. Rev. B 67, 134106 (2003).

${ }^{37}$ P. Rulis, L. Ouyang, and W. Y. Ching, Phys. Rev. B 70, 155104 (2004).

${ }^{38}$ See EPAPS Document No. E-JCPSA6-128-807824 for tables of the calculated structural data of the substitutional defects. For more information on EPAPS, see http://www.aip.org/pubservs/epaps.html.

${ }^{39}$ R. A. Shannon, Acta Crystallogr., Sect. A: Cryst. Phys., Diffr., Theor. Gen. Crystallogr. 32, 751 (1976).

${ }^{40}$ P. N. Pantel, J. Inorg. Nucl. Chem. 42, 1129 (1980).

${ }^{41}$ W. F. Neuman and B. J. Mulryan, Calcif. Tissue Res. 7, 133 (1971).

${ }^{42}$ R. Z. LeGeros, in Tooth Enamel IV, edited by R. W. Fearnhead and S. Suga (Elsevier, Amsterdam, 1984), pp. 32-36.

${ }^{43}$ S. Kannan, F. Goetz-Neunhoeffer, J. Neubauer, and J. M. F. Ferreira, J. Am. Ceram. Soc. 91, 1 (2008).

${ }^{44}$ N. K. Tripathy, P. N. Patel, and A. Panda, J. Solid State Chem. 80, 1 (1989).

${ }^{45}$ F. Miyaji, Y. Kono, and Y. Suyama, Mater. Res. Bull. 40, 209 (2005).

${ }^{46}$ A. C. Tas, Biomaterials 21, 1429 (2000). 